\title{
Good Agriculture Practices Application on Water Apple Farming in Demak Regency, Central Java Indonesia
}

\author{
Triyono $^{1^{*}}$, Sriyadi, Bahrul Ulum ${ }^{1}$ \\ ${ }^{1}$ Agribusiness Department, Universitas Muhammadiyah Yogyakarta \\ ${ }^{*}$ Corresponding author. Email: triyono@umy.ac.id
}

\begin{abstract}
Water apple is a local variety from Demak which has been SOP (standard operational procedures) related to water apple cultivation since 2010. The function of the water apple SOP is as a reference for GAP (Good Agriculture Practices) of water apple farming. The purpose of this study was to determine the level of application GAP and find out the factors related to the level of application GAP. We took three villages of water apple production centres as research location during 2018. Data collection was conducted through interviews with 72 randomly selected farmers. The level application of water apple GAP was analysed by the Likert Scale Scoring method, while the factors associated with the application of GAP were analysed by the Spearman Rank Correlation method. The results show that the application level of GAP on water apple farming is in medium category. Factors in the number of plants, land area, availability of capital, income, and input costs were positively related to the application level of GAP on water apple farming. Assistance to increase knowledge and skills is needed to increase the application of GAP so that the results of water apple farming will be better.
\end{abstract}

Keywords: water apple, GAP, application, farming

\section{INTRODUCTION}

Agricultural development has entered a new era, where development, which has so far seemed to be independent, then reflects more of a close relationship with other sectors. This is one of the basic strategies for high competitiveness in both the domestic and international markets. Agricultural commodities with bright prospects are horticultural commodities, this is in accordance with the opinion [1] which states that horticultural commodities, especially fruits, have bright prospects in the agricultural sector. The development of fruits has a very bright pattern of agribusiness and agro-industry because the demand for these commodities tends to increase, both in domestic and foreign markets.

Horticulture plays an important and strategic role because of its role as a major component of the hope food pattern. Horticultural commodities, especially vegetables and fruits, hold the most important part of the food balance, so they must be available at all times in sufficient quantities, of good quality, safe for consumption, affordable prices, and accessible to all levels of society. Horticultural commodities also have high economic value, so they can be a source of income for the community or farmers.

Horticultural commodities are grouped into four main groups, namely fruits, vegetables, ornamental plants and medicinal plants. One type of horticultural commodity that has business prospects and is quite excellent is water apple
(Syzygium samarangense). Water apple is one type of fruit that is well known to the public and has been used for food and treatment of several diseases [3].

One area that has started to develop water apple plants is Demak Regency. The Agriculture Office of Demak Regency in 2010 issued Standard Operating Procedures (SOPs) related to the cultivation of water apple in Demak Regency. It is hoped that the SOP will become a reference or GAP (Good Agriculture Practices) for farmers in carrying out water apple cultivation activities in Demak Regency. The SOP for water apple cultivation discusses water apple cultivation techniques which include the introduction of superior varieties, ways of farming, fertilization, irrigation, pest control, harvest and postharvest activities.

Table 1. Number of plants, production, and production average of apple plants in Demak Regency in 2018

\begin{tabular}{|c|c|c|c|}
\hline District & $\begin{array}{c}\text { Trees } \\
\text { Number }\end{array}$ & $\begin{array}{c}\text { Production } \\
\text { (kw) }\end{array}$ & $\begin{array}{c}\text { Production } \\
\text { average } \\
\text { (kg/tree) }\end{array}$ \\
\hline Guntur & 15,484 & 13,854 & 152.39 \\
\hline Mijen & 20,207 & 15,593 & 136.78 \\
\hline Demak & 12,542 & 10,982 & 367.66 \\
\hline Wonosalam & $\mathbf{3 4 , 2 7 4}$ & $\mathbf{1 1 , 1 2 0}$ & $\mathbf{7 3 . 6 9}$ \\
\hline Dempet & 10,668 & 6,192 & 135.23 \\
\hline Bonang & 5,883 & 8,118 & 157.17 \\
\hline
\end{tabular}




\begin{tabular}{|c|c|c|c|}
\hline Mranggen & 3,350 & 5,314 & 158.44 \\
\hline Wedung & 6,037 & 3,655 & 150.78 \\
\hline
\end{tabular}

Source: Demak Agriculture Office, 2019

Water apple in Demak Regency is spread across several Districts, where the highest average production is Demak District. Demak sub-district is the first district to develop water apple. The development of water apple in Demak Regency has started to spread in other sub-districts which have wider rice fields. Based on Table 1, the productivity of water apple varies between districts. The productivity of the commodity in Wonosalam District is the lowest compared to the productivity of other regions, although the plant population is the highest compared to other areas. Although the Department of Agriculture has issued a GAP (Good Agriculture Practices) related to the cultivation of water apple, the productivity is still not as expected. Therefore, the extent to which the practice of implementing Good Agriculture Practices of the commodity needs to be researched and the factors that influence it.

Research on the application of GAP in farming has been conducted by several previous researchers. [4] examined the application of GAP in food crop farming such as organic rice, while [5] examined GAP in maize farming. Meanwhile[6] and [7] examined GAP in horticultural farming, namely shallots. In addition, [8] GAP of medicinal plants for the development of traditional medicine in China.

GAP research on plantation crop farming was conducted by [9] on pepper farming. Meanwhile[10] and [11] examined GAP on oil palm farming. In addition, many researchers conducted research on GAP for sustainable agriculture, namely [12], [13], [14], [15], [16], and [17]. Furthermore, in the use of agricultural resources, several experts have researched GAP on the use of water and agricultural land, namely [18], [19], [20], [21], [22], [23] and [24].

Factors related to SOP/GAP are one of the objectives of this study, which was previously conducted by [4] to find a relationship between the application of SOP/GAP with factors of experience, education, land area, availability of capital, labour, price. selling output, and the purchase price of the input. Then,[10] wanted to know the relationship between compliance with GAP with factors of income, tree age, and level of training. In addition, research on the relationship between farmer factors that affect the application of organic farming SOPs [25] and examines the relationship between one's subjective understanding of environmental change and one's attitudes towards best agricultural management practices [26].

Research on water apple has also been carried out, namely about the feasibility of farming [27], factors that affect production [28], empowerment of water apple processing [29] and influence differences in land types [30].

Based on a review of previous studies, we have not found a study on the application of GAP in water apple farming. Water apple is a local variety in Central Java that has the potential to be developed but requires special care and skills for farmers in its development. Therefore, this paper will discuss the application of GAP and the factors that may be associated with it.

\section{METHOD}

The research method used in this research is descriptive method with a quantitative approach. According to [31], the descriptive method aims to describe the problem systematically, factually, and accurately regarding the facts and characteristics of a particular population or area. Quantitative research is a process of finding knowledge using quantitative data (numbers and scores) as a tool to analyse information about what you want to know.

The population of this study was farmers in the water apple production centre, Wonosalam District, Demak Regency, amounting to 1,091 farmers who were members of three association of farmer groups of three selected villages (Sidomulyo, Mranak, and Kendaldoyong). Each population of farmers group association are 511 memebers in Sido Maju, 295 members in Sekar Tani, and 285 members in Tani Sentosa. The number of samples in this study was calculated based on the analysis of sample size determination [32], with the following formulations:

$$
\mathrm{n}=\frac{\mathrm{NZ}^{2} \mathrm{~S}^{2}}{\mathrm{Nd}^{2}+\mathrm{Z}^{2} \mathrm{~S}^{2}}
$$

Information:

$\mathrm{n}=$ Number of samples

$\mathrm{N}=$ Total population

$\mathrm{Z}=$ Degree of confidence $(95 \%=1.96)$

$\mathrm{S}^{2}=$ Sample variant $(5 \%)$

$\mathrm{d}=$ Degree of deviation $(5 \%)$

Based on this formula, a total sample of 72 farmers was obtained. The number of samples per association was taken using the proportional random sampling method. Based on the calculation, each association sample was 34 farmers in Sido Maju, 20 farmers from Sekar Tani, and 18 farmers from Sentosa.

The level of application of Good Agriculture Practices (GAP) in water apple farming is calculated using a Likert scale. According to [31], the Likert Scale Method is a measurement method by confronting a respondent with a positive or negative question and then being asked to provide an answer to that question by "never doing", "rarely doing", "sometimes do "," do often, "and" always do. " The answer is given a score of $0,1,2,3$, and 4, respectively.

Table 2. Details of aspects of applying GAP in water apple farming

\begin{tabular}{|c|c|c|c|}
\hline \multirow{2}{*}{ No } & \multirow{2}{*}{ SOP/GAP Aspects } & \multicolumn{2}{|c|}{ Application Score } \\
\cline { 3 - 4 } & & Lowest & Highest \\
\hline 1 & Site selection & 0 & 4 \\
\hline 2 & Garden sketching & 0 & 4 \\
\hline
\end{tabular}




\begin{tabular}{|c|c|c|c|}
\hline \multirow{2}{*}{ No } & \multirow{2}{*}{ SOP/GAP Aspects } & \multicolumn{2}{|c|}{ Application Score } \\
\cline { 3 - 4 } & Lowest & Highest \\
\hline 3 & $\begin{array}{c}\text { Planting time } \\
\text { determination }\end{array}$ & 0 & 4 \\
\hline 4 & Land preparation & 0 & 4 \\
\hline 5 & Preparation of seeds & 0 & 4 \\
\hline 6 & Planting & 0 & 4 \\
\hline 7 & Fertilization & 0 & 4 \\
\hline 8 & irrigation & 0 & 4 \\
\hline 9 & Pruning & 0 & 4 \\
\hline 10 & Pest control & 0 & 4 \\
\hline 11 & Garden sanitation & 0 & 4 \\
\hline 12 & Thinning the fruit & 0 & 4 \\
\hline 13 & Fruit wrapping & 0 & 4 \\
\hline 14 & $\begin{array}{c}\text { Harvest time } \\
\text { determination }\end{array}$ & 0 & 4 \\
\hline 15 & Fruit picking & 0 & 4 \\
\hline 16 & Fruit collection & 0 & 4 \\
\hline 17 & Cleaning, sorting and & 0 & 4 \\
\hline 18 & Packaging and labeling & 0 & 4 \\
\hline & Total Score & $\mathbf{0}$ & $\mathbf{7 2}$ \\
\hline
\end{tabular}

After the data was collected, then a descriptive analysis was carried out by categorizing the level of GAP application in the water apple farming, namely high, medium, and low. Categorization of levels is done by subtracting the highest score from the lowest score then dividing it by 3 which is the range of each category level, with the formula:

$$
I_{\text {total }}=\frac{72-0}{3}=24 \quad \text { or } I_{\text {Aspects }}=\frac{4-0}{3}=1.33
$$

The results of the interval formula show that the criteria for class division of the application level of GAP in the water apple farming are in the following table:

Table 3. Determination of the level of application of GAP in water apple farming

\begin{tabular}{|c|c|c|}
\hline Score & Score Achievement & Intensity Category \\
\hline \multirow{2}{*}{$\begin{array}{c}\text { Total } \\
0-72\end{array}$} & $49-72$ & High \\
\cline { 2 - 3 } & $25-48$ & Medium \\
\cline { 2 - 3 } & $0-24$ & Low \\
\hline $\begin{array}{c}\text { Per Aspect } \\
0-4\end{array}$ & $2.67-4.00$ & High \\
\cline { 2 - 3 } & $1.34-2.66$ & Medium \\
\cline { 2 - 3 } & $0.00-1.33$ & Low \\
\hline
\end{tabular}

The factors associated with the application of GAP were analysed using Rank Spearman's correlation. According to [33] and [34] the value of the rank spearman's correlation coefficient can be calculated by the formula:

$$
\mathrm{r}_{\mathrm{s}}=1-\frac{6 \sum_{\mathrm{i}=1}^{\mathrm{n}} \mathrm{d}_{\mathrm{i}}^{2}}{\mathrm{n}\left(\mathrm{n}^{2}-1\right.}
$$

$\mathrm{rs}=$ spearmant rank correlation coefficient

$\mathrm{di}=$ difference between rank pairs

$\mathrm{n}=$ number of rank pairs

\section{RESULT AND DISCUSSION}

\subsection{Application of GAP in Water apple Farming}

In general, farmers have applied cultivation techniques in accordance with the water apple GAP guidelines, however, not all aspects of GAP are carried out by farmers. The level of application of GAP in water apple farming is 28.38. This result is the same as the findings of [25], namely the moderate level of GAP application. This is different from the findings of [4] and [10] which are in the fairly high category, and [6] in the low category.

Although there are several aspects of water apple GAP that are applied in the high category, most of them are in the low and medium categories. Farmers do water apple farming based on knowledge from experience and trials that they do themselves. Farmers' experiences come from generation to generation from previous farming families. Meanwhile, the trial was carried out by farmers because they learned from other water apple farmers or based on the farmers' own thinking. In addition, farmers get knowledge from extension activities.

Table 4. Scores and categories of GAP application for water apple farming

\begin{tabular}{|c|c|c|c|}
\hline \multirow{2}{*}{ No } & \multirow{2}{*}{ SOP/GAP Aspects } & \multicolumn{2}{|c|}{ Appliction } \\
\cline { 3 - 4 } & Score & Category \\
\hline $\mathbf{1}$ & Site selection & $\mathbf{3 . 0 0}$ & High \\
\hline 2 & Garden sketching & 0.62 & Low \\
\hline 3 & $\begin{array}{c}\text { Planting time } \\
\text { determination }\end{array}$ & 2.41 & Medium \\
\hline 4 & Land preparation & 2.44 & Medium \\
\hline 5 & Preparation of seeds & 1.99 & Medium \\
\hline 6 & Planting & 2.43 & Medium \\
\hline 7 & Fertilization & 0.93 & Low \\
\hline 8 & irrigation & 2.41 & Medium \\
\hline 9 & Pruning & 0.99 & Low \\
\hline 10 & Pest control & 2.23 & Medium \\
\hline 11 & Garden sanitation & 2.24 & Medium \\
\hline 12 & Thinning the fruit & 1.00 & Low \\
\hline 13 & Fruit wrapping & 0.36 & Low \\
\hline 14 & $\begin{array}{c}\text { Harvest time } \\
\text { determination }\end{array}$ & 2.15 & Medium \\
\hline $\mathbf{1 5}$ & Fruit picking & $\mathbf{2 . 9 0}$ & High \\
\hline 16 & Fruit collection & 0.19 & Medium \\
\hline 17 & Cleaning, sorting and & 0.08 & Medium \\
\hline 18 & Packaging and labeling & 0.00 & Low \\
\hline & Total Score & $\mathbf{2 8 . 3 8}$ & Medium \\
\hline
\end{tabular}

Where: 
Farmers also think that there are some aspects of water apple GAP that are difficult or unnecessary. The GAP aspects are aspects of garden sketching, pruning aspects, fruit thinning aspects, fruit wrapping aspects, and postharvest activities. In post-harvest activities of water apple, such as aspects of cleaning, sorting, and grading, as well as aspects of packaging and labelling, most farmers do not do it because these activities are usually carried out by traders or collectors to save on water apple farming costs.

Only aspects of site selection and fruit picking that have been implemented according to the procedure or application are high. The geographic conditions of the research location strongly support the cultivation of water apple to grow, develop and produce. However, the current climate conditions are very unpredictable and uncertain, especially the temperature and the rainy season. This results in the indicators of rainfall and air temperature in the medium category. Meanwhile, picking fruit is an activity that is relatively easy for farmers to do even though it is still manual with simple technology.

Most of the GAP implementation of water apple is still in the medium category. This occurs in the aspects of determining planting time, land preparation, seed preparation, planting, irrigation, controlling plant pests, garden sanitation, and determining harvest time. Farmers still rarely carry out activities on every aspect of the GAP. There are quite a lot of activities that must be carried out by farmers in these various aspects and must be coherent according to procedures. However, farmers carry out these activities based on the knowledge and skills they have so far and do not pay attention to the complete GAP guidelines. Farmers already have knowledge regarding the proper planting time between March-April or when there is sufficient water. This knowledge has been acquired by farmers from generation to generation. Although farmers sometimes plant outside the rainy season due to a lack of definite information on when the rainy season occurs, the water needs are taken from water sources (rivers), namely the Tuntang River and Kedung Ombo Reservoir from the nearest location.

Farmers carry out the activities of clearing land, stake installation determining water channels, making water channels, making planting holes. However, in practice it is rarely carried out according to GAP guidelines. In addition, the application is carried out if there is a desire from the farmer not because of necessity or need for the garden area and water apple plants.

Farmers prepare their own seeds by grafting the parent plants they have. Usually the age of the grafted plants is ready for planting when they are 1 year old or the plants already have roots. Preparation of seeds for farmers has been known for a long time because it is based on knowledge from generation to generation. Apart from that, farmers planting seedlings is sufficiently in accordance with GAP. However, with regard to the spacing of farmers, it is often not in accordance with the recommended spacing $(7 \times$
$7 \mathrm{~m}$ or $8 \times 8 \mathrm{~m}$ ), which is sometimes very less or more than the spacing, because farmers adjust to land conditions. The shade used is the type of tree plants that can grow tall around the garden, besides that farmers also use other types of cultivated plants in the garden area.

In terms of maintenance, farmers perform irrigation during the dry season from the Tuntang River and Kedung Ombo Reservoir using a water pump machine. However, this method cannot be evenly distributed due to the lack of technology used by farmers. In addition, for farmers who have land far from water sources, watering is quite difficult. In addition, farmers carry out pest control routinely but do not record pest control. The types of pesticides that are often used are larvin, starban, lanate, and abacel.

With regard to garden sanitation, farmers check the location of the garden every morning. However, garden sanitation activities are usually only carried out by farmers during the dry season and before the main harvest. This is done to save labour in garden maintenance. Usually the garden sanitation activities carried out by farmers are cleaning weeds with sickles, throwing loose fruit and garbage in the garbage pits, and burn

At harvest time, the farmer determines the harvest time based on market demand, that is, when a merchant wants to buy, the farmer does the harvesting or picking fruit. However, based on observations in the field, farmers did not see the documentation or information on the notes on the label because the farmers did not do that. Water apple harvest season can reach 1-3 times a year depending on plant care and environmental conditions.

The low GAP application occurs in the aspects of garden sketching, fertilizing, pruning, thinning, wrapping, collecting fruit and cleaning, sorting, grading as well as packaging and labelling. This happens because farmers rarely or almost never implement activities on various aspects of the GAP. Only a small part of the activity indicators from the GAP aspect above were carried out by farmers according to procedures. Farmers have never done a sketch or design of a water apple garden because it is considered unnecessary and they have already remembered it. In addition, farmers' knowledge and skills in making garden sketch designs are still lacking and if they use services, it will increase farming costing them.

In terms of plant care, farmers do fertilization not based on GAP, but based on farmers' knowledge. Farmers do not calculate fertilizer requirements per plant as a reference dose. Fertilization is done by sprinkling it around the roots of the plant. The fertilizers that are often used are compound fertilizers such as pearl fertilizer and NPK (Nitrogen, Phosphor, Kalium). In addition, farmers also use hormones or growth stimulant.

In the case of fruit care, farmers thinner fruit only when necessary, because farmers think that thinning fruit will reduce fruit productivity. The thinning of fruit can also result in the current crop being wasted. Actually, the goal of 
thinning fruit is to stabilize plant productivity and improve fruit quality. The impact if not thinning the fruit will result in stress for the plant. In addition, farmers rarely wrap fruit because it adds to operational costs such as purchasing plastics and wages for labour. This is risky because there can be damage due to pest attacks, especially fruit flies.

Most of the farmers do not carry out post-harvest activities, one of which is fruit collection. Fruit collection is carried out by traders or collectors. The problem of knowledge and technology possessed by farmers is still lacking to carry out post-harvest activities of water apple fruit. This causes farmers not to carry out post-harvest activities including cleaning, sorting, and grading. Most of the harvest and post-harvest activities are carried out by collecting traders. However, there are farmers who sell fruit directly, so they carry out cleaning, sorting, and grading activities so that product prices are higher. In addition, farmers also do not carry out packaging and labelling because it requires a large amount of money, especially for purchasing containers (cardboard). Water apple farmers' ability is only limited to production, it does not reach the realm of post-harvest and marketing, so farmers do not understand this activity.

\subsection{Factors Related to the Level of GAP Implementation}

The factors related to the level of application of GAP in the cultivation of water apple need to be known, because these factors can determine the success of GAP application in water apple farming. The following is a table of the results of the Spearman Rank Correlation analysis.

Table 5. Results of the Spearman Rank Correlation analysis on the factors associated with the level of GAP application of water apple

\begin{tabular}{|c|c|c|c|}
\hline No & Factors & $\begin{array}{c}\text { Coefficient } \\
\text { (Rs) }\end{array}$ & Sig. \\
\hline 1 & Age & 0,024 & 0,844 \\
\hline 2 & Experience & 0,039 & 0,439 \\
\hline 3 & Education & $-0,044$ & 0,716 \\
\hline 4 & Family & $-0,118$ & 0,324 \\
\hline 5 & Plants & 0,440 & $0,000^{* * *}$ \\
\hline 6 & Land & 0,482 & $0,000^{* * *}$ \\
\hline 7 & Capital availability & 0,386 & $0,001^{* * *}$ \\
\hline 8 & Income & 0,316 & $0,007^{* * *}$ \\
\hline 9 & Input cost & 0,311 & $0,008^{* * *}$ \\
\hline
\end{tabular}

Note: $* * *)$ The correlation is significant at $1 \%$ error rate

Table 5 shows the results of testing the relationship of each factor to the level of GAP application in water apple farming. Factors that have a significant relationship with the error rate of $1 \%$ with the level of GAP application are the number of plants, land area, capital availability, income, and input costs. Meanwhile age, experience, education, and family dependents are not related to the level of GAP application. Based on research by [4] the level of application of GAP is related to the availability of capital, the selling price of output, and the purchase price of inputs, while the factors of experience, education, land area, and labour are not significant.

The results of the analysis using the Spearman Rank Correlation show that the number of plants has a positive correlation with the level of GAP application with a correlation coefficient of 0.440 . This means that there is a significant relationship between the number of plants and the level of GAP application. The results of research carried out in the field showed that the number of plants owned by farmers ranged from 6 to 200 trees or the average number of farmers' plants was 45 trees. The large number of farmers' crops makes farmers more focused on running their farming. Farmers are more focused on implementing GAP in the cultivation of water apple. If farmers implement GAP well, there is hope for an increase in the production and quality of water apple. This is also a hope for increasing it farming income.

The land area factor has a positive correlation with the level of GAP application of 0.482 . This means that there is a very significant relationship between land area and the level of GAP application. Based on field observations, it shows that the land area owned by the farmers is $100-20,000$ $\mathrm{m}^{2}$ or the average land area of the farmers is $2,389 \mathrm{~m}^{2}$. The large area of farmers' land makes farmers more focused on running their farming with the application of GAP. The types of land used are dry land / gardens and wetlands / rice fields.

The availability of farmer capital has a positive correlation with the level of GAP application of 0.386 . The positive correlation result means that the high availability of farmer capital affects the level of GAP application. The higher the availability of capital owned, the higher the level of application of water apple GAP. Likewise, on the other hand, the lower the availability of capital, the lower the GAP application in the water apple farming. Based on field observations, the capital issued by farmers is Rp. 1,000,000 - Rp. 40,000,000 per year or an average of Rp. 8,000,000 per year of farming. The high availability of capital will be sufficient to meet the costs of cultivating water apple.

Farmers' income has a positive correlation with the level of GAP application of 0.316 . The positive correlation result means that the high income of farmers affects the level of GAP application in the water apple farming. The higher the income obtained, the higher the level of application of GAP water apple. Likewise, on the contrary, the lower the income earned, the GAP application in the water apple farming will also be lower. Based on field observations, the income of water apple farmers is Rp. 1,328,600 - Rp. 41,482,333 per year or an average of Rp. 10,586,971 per year of farming. The high income will be sufficient to meet the needs of the farming family. 
Production input costs have a positive correlation with the level of GAP application of 0.311 . Based on field observations, the production input costs incurred by water apple farmers are Rp. 593,400 - Rp. 21,880,000 per year or an average of Rp. 5,283,830 per year of farming. The high input costs will be sufficient to meet the farming needs of water apple. So, the higher the input costs incurred by farmers, the higher the level of GAP application in water apple farming. The input costs incurred by farmers are in the form of fertilizers, pesticides, hormones or stimulant growth, plastics, and other costs such as fuel and fruit fly traps.

\section{CONCLUSION}

In general, the application of GAP in the water apple farming is in the medium category. In detail, the aspects of site selection and fruit picking are included in the high category, aspects of determining harvest time, land preparation, seed preparation, planting, irrigation, pest control, garden sanitation, and harvest timing are in the medium category, and garden sketching aspects. fertilizing, pruning, thinning fruit, packing fruit, collecting fruit, cleaning, sorting and grading, as well as packaging and labelling, are included in the low category.

The application of GAP in water apple farming is positively related to the number of plants, land area, availability of capital, income, and input costs. This means that the higher the number of plants, the area of land, the availability of capital, income, and input costs, the higher the level of GAP application in water apple farming.

Farmers should increase the application of every aspect of GAP activities in the cultivation of water apple, because there are still many aspects that are in the low category such as aspects of garden sketching, fertilization, pruning, fruit thinning, fruit wrapping, fruit collection, cleaning, sorting, and grading. and packaging and labelling.

The Department of Agriculture and Food of Demak and the Agricultural Extension Agency should design and carry out extension activities as well as assistance in implementing GAP of water apple, so as to increase understanding of knowledge and technology as well as farming skills of water apple. In addition, the government should facilitate farmers in accessing capital by establishing a Micro Finance Institution (MFI) for water apple farmers.

\section{REFERENCES}

[1] H. Ariyanto, Budidaya Tanaman Buah-buahan. Yogyakarta: PT. Citra Aji Parmana, 2006.

[2] Direktorat Jenderal Hortikultura, "Rencana Kinerja Direktorat Jenderal Hortikultura Tahun 2011," Jakarta, 2011.

[3] Cahyono, Sukses Budidaya Jambu Air di Pekarangan \& Perkebunan. Yogyakarta: Lily Publisher, 2010.
[4] S. Sriyadi, E. I. Istiyanti, and F. Risvansuna Fivintari, "Evaluasi Penerapan Standard Operating ProcedureGood Agriculture Practice (SOP-GAP) pada Usahatani Padi Organik di Kabupaten Bantul," Agrar. J. Agribus. Rural Dev. Res., vol. 1, no. 2, pp. 78-84, 2015, doi: 10.18196/agr.1211.

[5] C. Tonitto, P. B. Woodbury, and E. L. McLellan, "Defining a best practice methodology for modeling the environmental performance of agriculture," Environ. Sci. Policy, vol. 87, pp. 64-73, 2018, doi: 10.1016/j.envsci.2018.04.009.

[6] S. Suharni, L. R. Waluyati, and J. Jamhari, "The Application of Good Agriculture Practices(GAP) of Shallot in Bantul Regency," Agro Ekon., vol. 28, no. 1, p. 48, 2017, doi: 10.22146/jae.25022.

[7] Tavi Supriana, Rahmanta, and Nurul Fajriah Pinem, "Pemberdayaan Petani Bawang Merah Melalui Penerapan Spo (Standar Prosedur Operasional) Bawang Merah Spesifik Lokasi Yang Berbasis Gap (Good Agricultural Practices)," ABDIMAS Talent. J. Pengabdi. Kpd. Masy., vol. 2, no. 1, pp. 66-78, 2017, doi: 10.32734/abdimastalenta.v2i1.2201.

[8] C. Li, Z. Yan, L. Zhang, and Y. Li, "Research and implementation of good agricultural practice for traditional Chinese medicinal materials in Jilin Province, China," J. Ginseng Res., vol. 38, no. 4, pp. 227-232, 2014, doi: 10.1016/j.jgr.2014.05.007.

[9] F. Setiawan, F. Inonu, and R. Sitorus, "Implementasi GAP (Good Agriculture Practice) Lada dan Pengaruhnya Terhadap Produktivitas Lada di Desa Petaling Banjar, Kecamatan Mendo Barat," Enviagro, J. Pertan. dan Lingkung., vol. 8, no. 2, pp. 72-82, 2015.

[10] S. Somnuek and M. Slingerland, "CAN GOOD AGRICULTURAL PRACTICES SUSTAIN OIL PALM YIELDS for BIOENERGY PRODUCTION in NORTHEAST THAILAND?," Exp. Agric., vol. 54, no. 6, pp. 915-930, 2018, doi: $10.1017 / \mathrm{S} 0014479717000497$.

[11] I. Jelsma, L. S. Woittiez, J. Ollivier, and A. H. Dharmawan, "Do wealthy farmers implement better agricultural practices? An assessment of implementation of Good Agricultural Practices among different types of independent oil palm smallholders in Riau, Indonesia," Agric. Syst., vol. 170, pp. 63-76, 2019, doi: 10.1016/j.agsy.2018.11.004.

[12] D. P. Sari, R. F. Syafruddin, and M. Kadir, "Penerapan Prinsip-Prinsip Good Agricultural Practice (GAP) Untuk Pertanian Berkelanjutan Di Kecamatan Tinggi Moncong Kabupaten Gowa," J. Galung Trop., vol. 5, no. 3, pp. 151-163, 2016.

[13] Y. S. Tey et al., "A Means-End Chain Approach to Explaining the Adoption of Good Agricultural Practices Certification Schemes: The Case of Malaysian Vegetable Farmers," J. Agric. Environ. Ethics, vol. 28, no. 5, pp. 977-990, 2015, doi: 


\section{$10.1007 / \mathrm{s} 10806-015-9572-9$.}

[14] V. J. P. D. Martinho, "Best management practices from agricultural economics: Mitigating air, soil and water pollution," Sci. Total Environ., vol. 688, pp. 346-360, 2019, doi: 10.1016/j.scitotenv.2019.06.199.

[15] P. Borrelli, K. Paustian, P. Panagos, A. Jones, B. Schütt, and E. Lugato, "Effect of Good Agricultural and Environmental Conditions on erosion and soil organic carbon balance: A national case study," Land use policy, vol. 50, pp. 408-421, 2016, doi: 10.1016/j.landusepol.2015.09.033.

[16] J. Jordan and D. Constance, "Sustainable agriculture and the social sciences: getting beyond best management practices and into food systems," South. Rural Sociol., vol. 23, no. 1, pp. 1-22, 2008.

[17] J. Ingram, "Agronomist-farmer knowledge encounters: An analysis of knowledge exchange in the context of best management practices in England," Agric. Human Values, vol. 25, no. 3, pp. 405-418, 2008, doi: 10.1007/s10460-008-9134-0.

[18] K. W. Gabel, J. D. Wehr, and K. M. Truhn, "Assessment of the effectiveness of best management practices for streams draining agricultural landscapes using diatoms and macroinvertebrates," Hydrobiologia, vol. 680, no. 1, pp. 247-264, 2012, doi: 10.1007/s10750-011-0933-8.

[19] J. McGuire, L. W. Morton, and A. D. Cast, "Reconstructing the good farmer identity: Shifts in farmer identities and farm management practices to improve water quality," Agric. Human Values, vol. 30, no. 1, pp. 57-69, 2013, doi: 10.1007/s10460-0129381-y.

[20] Y. Liu et al., "Evaluating efficiencies and costeffectiveness of best management practices in improving agricultural water quality using integrated SWAT and cost evaluation tool," J. Hydrol., vol. 577, 2019, doi: 10.1016/j.jhydrol.2019.123965.

[21] Z. Bai et al., "Effects of agricultural management practices on soil quality: A review of long-term experiments for Europe and China," Agric. Ecosyst. Environ., vol. 265, pp. 1-7, 2018, doi: 10.1016/j.agee.2018.05.028.

[22] A. Engebretsen, R. D. Vogt, and M. Bechmann, "SWAT model uncertainties and cumulative probability for decreased phosphorus loading by agricultural Best Management Practices," Catena, vol. 175, pp. 154-166, 2019, doi: 10.1016/j.catena.2018.12.004.

[23] R. W. McDowell, C. W. Gray, K. C. Cameron, H. J. Di, and R. Pellow, "The efficacy of good practice to prevent long-term leaching losses of phosphorus from an irrigated dairy farm," Agric. Ecosyst. Environ., vol.
273, pp. 86-94, 2019, doi: 10.1016/j.agee.2018.12.007.

[24] S. K. Himanshu, A. Pandey, B. Yadav, and A. Gupta, "Evaluation of best management practices for sediment and nutrient loss control using SWAT model," Soil Tillage Res., vol. 192, pp. 42-58, 2019, doi: 10.1016/j.still.2019.04.016.

[25] A. Charina, R. A. B. Kusumo, A. H. Sadeli, and Y. Deliana, "Faktor-faktor yang Mempengaruhi Petani dalam Menerapkan Standar Operasional Prosedur (SOP) Sistem Pertanian Organik di Kabupaten Bandung Barat," J. Penyul., vol. 14, no. 1, 2018, doi: 10.25015/penyuluhan.v14i1.16752.

[26] D. Schall, D. Lansing, P. Leisnham, A. Shirmohammadi, H. Montas, and T. Hutson, "Understanding stakeholder perspectives on agricultural best management practices and environmental change in the Chesapeake Bay: A Q methodology study," J. Rural Stud., vol. 60, pp. 2131, 2018, doi: 10.1016/j.jrurstud.2018.03.003.

[27] E. D. N. Muhammad Suheli, Dewi Hastuti, “Analisis Kelayakan Usahatani Jambu Ait Merah Delima (Syzygium samarangense (Blume) Merr. \& Perry.) di Kabupaten Demak (Studi Kasus di Kelurahan Betokan Kecamatan Demak Kabupaten Demak)," Mediagro, vol. 9, no. 2, pp. 46-54, 2013.

[28] Setiarini, "Faktor-Faktor Yang Mempengaruhi Produksi Jambu Air Di Desa Wonosari Kabupaten Demak," Econ. Dev. Anal. J., vol. 4, no. 3, pp. 308 315, 2015, doi: 10.15294/edaj.v4i3.14838.

[29] W. Roessali, P. Sasmoko, and . Darwanto, "Pemberdayaan Masyarakat melalui Pengolahan Jambu Merah Delima (Syzygium semarangense) di Kabupaten Demak," Agrokreatif J. Ilm. Pengabdi. Kpd. Masy., vol. 3, no. 2, p. 123, 2017, doi: 10.29244/agrokreatif.3.2.123-128.

[30] Pertiwi, M. D., D. Prajitno, and D. Shiddieq, "Pengaruh Perbedaan Jenis Lahan dan Terapan Budidaya Terhadap Produksi Jambu Air Merah Delima," Ilmu Pertan., vol. 15, no. 2, pp. 61-68, 2013, doi: 10.22146/ipas.2516.

[31] U. Rianse and Abdi, Metodologi Penelitian Sosial dan Ekonomi (Teori dan Aplikasi). ALFABETA, 2012.

[32] Sugiarto, D. Siagian, L. T. Sunaryanto, and D. S. Oetomo, Teknik Sampling. Jakarta: Gramedia Pustaka utama, 2003.

[33] Djarwanto, Statistik Non Parametrik. Yogyakarta: BPFE UGM, 1991.

[34] Sugiyono, Metode Penelitian Bisnis (Pendekatan Kuantitatif, Kualitatif, Kombinasi dan R\&D). Yogyakarta: Alfabeta, 2017. 